\title{
A cuckoo in wolves' clothing? Chemical mimicry in a specialized cuckoo wasp of the European beewolf (Hymenoptera, Chrysididae and Crabronidae)
}

\author{
Erhard Strohm1,2, Johannes Kroiss*1,2, Gudrun Herzner1,2, Claudia Laurien- \\ Kehnen ${ }^{3,4}$, Wilhelm Boland ${ }^{5}$, Peter Schreier ${ }^{6}$ and Thomas Schmitt ${ }^{2,7}$
}

\begin{abstract}
Address: ${ }^{1}$ University of Regensburg, Institute of Zoology, D-93040 Regensburg, Germany, ${ }^{2}$ University of Würzburg, Department of Animal Ecology and Tropical Biology, Am Hubland, 97074 Würzburg, Germany, ${ }^{3}$ University of Bonn, Zoological Institute, Poppelsdorfer Schloss, 53115 Bonn, Germany, ${ }^{4}$ University of Bielefeld, Behavioural Biology, 33501 Bielefeld, Germany, ${ }^{5}$ Max Planck Institute for Chemical Ecology, Department for Bioorganic Chemistry, 07745 Jena, Germany, ${ }^{6}$ University of Würzburg, Department of Food Chemistry, Am Hubland, 97074 Würzburg, Germany and ${ }^{7}$ University of Freiburg, Institute of Biology I (Zoology), Hauptstr. 1, 79104 Freiburg i. Br., Germany
\end{abstract}

Email: Erhard Strohm - erhard.strohm@biologie.uni-regensburg.de; Johannes Kroiss* - johannes.kroiss@biologie.uni-regensburg.de; Gudrun Herzner - gudrun.herzner@biologie.uni-regensburg.de; Claudia Laurien-Kehnen - claudia.laurien@uni-bielefeld.de; Wilhelm Boland - boland@ice.mpg.de; Peter Schreier - schreier@pzlc.uni-wuerzburg.de; Thomas Schmitt - thomas.schmitt@biologie.unifreiburg.de

* Corresponding author

Published: II January 2008

Frontiers in Zoology 2008, 5:2 doi:10.1186/1742-9994-5-2
Received: 30 May 2007

Accepted: II January 2008

This article is available from: http://www.frontiersinzoology.com/content/5/I/2

(C) 2008 Strohm et al; licensee BioMed Central Ltd.

This is an Open Access article distributed under the terms of the Creative Commons Attribution License (http://creativecommons.org/licenses/by/2.0), which permits unrestricted use, distribution, and reproduction in any medium, provided the original work is properly cited.

\begin{abstract}
Background: Host-parasite interactions are among the most important biotic relationships. Host species should evolve mechanisms to detect their enemies and employ appropriate counterstrategies. Parasites, in turn, should evolve mechanisms to evade detection and thus maximize their success. Females of the European beewolf (Philanthus triangulum, Hymenoptera, Crabronidae) hunt exclusively honeybee workers as food for their progeny. The brood cells containing the paralyzed bees are severely threatened by a highly specialized cuckoo wasp (Hedychrum rutilans, Hymenoptera, Chrysididae). Female cuckoo wasps enter beewolf nests to oviposit on paralyzed bees that are temporarily couched in the nest burrow. The cuckoo wasp larva kills the beewolf larva and feeds on it and the bees. Here, we investigated whether $\mathrm{H}$. rutilans evades detection by its host. Since chemical senses are most important in the dark nest, we hypothesized that the cuckoo wasp might employ chemical camouflage.
\end{abstract}

Results: Field observations suggest that cuckoo wasps are attacked by beewolves in front of their nest, most probably after being recognized visually. In contrast, beewolves seem not to detect signs of the presence of these parasitoids neither when these had visited the nest nor when directly encountered in the dark nest burrow.

In a recognition bioassay in observation cages, beewolf females responded significantly less frequently to filter paper discs treated with a cuticular extract from $\mathrm{H}$. rutilans females, than to filter paper discs treated with an extract from another cuckoo wasp species (Chrysis viridula). The behavior to paper discs treated with a cuticular extract from $H$. rutilans females did not differ significantly from the behavior towards filter paper discs treated with the solvent only.

We hypothesized that cuckoo wasps either mimic the chemistry of their beewolf host or their host's prey. We tested this hypothesis using GC-MS analyses of the cuticles of male and female 
beewolves, cuckoo wasps, and honeybee workers. Cuticle extracts of Hedychrum nobile (Hymenoptera: Chrysididae) and Cerceris arenaria (Hymenoptera: Crabronidae) were used as outgroups. There was little congruence with regard to cuticular compounds between $H$. rutilans females and honeybees as well as females of $C$. arenaria and $H$. nobile. However, there was a considerable similarity between beewolf females and $H$. rutilans females. Beewolf females show a striking dimorphism regarding their cuticular hydrocarbons with one morph having (Z)-9-C25:I and the other morph having (Z)-9-C27:I as the major component. $H$. rutilans females were more similar to the morph having (Z)-9-C27:I as the main component.

Conclusion: We conclude that $H$. rutilans females closely mimic the composition of cuticular compounds of their host species $P$. triangulum. The occurrence of isomeric forms of certain compounds on the cuticles of the cuckoo wasps but their absence on beewolf females suggests that cuckoo wasps synthesize the cuticular compounds rather than sequester them from their host. Thus, the behavioral data and the chemical analysis provide evidence that a specialized cuckoo wasp exhibits chemical mimicry of the odor of its host. This probably allows the cuckoo wasp to enter the nest with a reduced risk of being detected by olfaction and without leaving traitorous chemical traces.

\section{Background}

The interaction between hosts and parasites or parasitoids is one of the most important forces driving evolutionary and ecological processes [1]. In order to reduce the impact of parasitoids, host species may evolve mechanisms to detect their enemies and employ adequate counterstrategies [2-5]. Parasitoids, in turn, are selected to evolve mechanisms that reduce the probability of being detected by their hosts to circumvent such countermeasures. This sets the stage for repeated cycles of adaptations and counteradaptations ("evolutionary arms race" [6-10]) between hosts and parasites, especially if the parasitoid is highly specialized on a single host species and has a large impact on host fitness $[2,11,12]$.

Progeny of brood caring bees and wasps are particularly susceptible to parasitism [13-15]. Females of these species store large amounts of valuable nutrients as larval provisions in brood cells. These valuable resources attract a variety of brood parasites, either cleptoparasites that reduce the amount of resources available to the host's progeny or parasitoids that obligatorily kill the host larvae. Mostly, females of these parasitic species have to enter the nest or the brood cell to deposit eggs or larvae. Thus, the traces that are left by female brood parasites might be detected by the host. As a result, the hosts might abandon the nests or remove or destroy eggs of brood parasites $[5,16]$. Brood parasites might also be encountered in the nest by the host and might be driven away, injured, or even killed (E. Strohm, unpubl. observations). Since insects heavily rely on their chemical senses for any kind of recognition or localization process $[1,17,18]$, concealment of a brood parasite's actual or previous presence will require chemical camouflage (compounds sequestered from the host or the host's nest) or chemical mimicry (compounds synthesized by the mimic, definitions sensu
[19]). In this study, we investigated the interaction between a hunting wasp, the European beewolf, Philanthus triangulum (Hymenoptera, Crabronidae) and its highly specialized brood parasitoid Hedychrum rutilans (Hymenoptera, Chrysididae). We investigated the following questions: Are cuckoo wasps (H. rutilans) detected and recognized by beewolf females at all? Is there a difference in host response towards the cuckoos outside and inside the nest and do the cuticular hydrocarbons play a role for the detection of the cuckoo wasps inside the nest? Is the chemical composition of the cuticular hydrocarbons of $H$. rutilans females similar to their host or to their host's prey?

Females of the European beewolf hunt honeybee workers (Hymenoptera, Apidae) as food for their progeny. Several paralyzed bees are temporarily couched in the main burrow (up to $1 \mathrm{~m}$ long) of the underground nest (see [20] for details on nest architecture). Eventually, the female closes the nest entrance, excavates a side burrow and a terminal brood cell, brings in one to six paralyzed bees, and oviposits on one of the bees [21]. Thereupon, she carefully closes the side burrow and subsequently has no contact to her progeny.

The cuckoo wasp, H. rutilans, is a specialized brood parasitoid of the genus Philanthus $[16,22]$. However, since in Central Europe only one member of the genus, $P$. triangulum, is fairly abundant, $H$. rutilans is effectively monospecific in this region. This considerable degree of specialization is expressed by the unique oviposition strategy of $H$. rutilans. Most chrysidid wasps oviposit into the brood cell of their hosts at a defined stage of the provisioning cycle or after the brood cell has been finally closed [22]. In beewolves, however, the brood cell is excavated only after the female has brought in the bees and the nest entrance has been closed. Thus, the nest is blocked up and 
the female is attendant until the brood cell is finally closed. This leaves little opportunity for a cuckoo wasp to deposit an egg in the brood cell. As a consequence, $H$. rutilans females pursue two alternative strategies. Either they rapidly pounce and oviposit on a paralyzed bee when the female alights with its prey and enters the burrow ([23], E. Strohm unpubl. observation), or $H$. rutilans females wait in front of the nest until the host female leaves to forage and then enter the burrow and oviposit on the paralyzed bees that are temporarily couched there [22]. Thus, $H$. rutilans use the paralyzed bees as a Trojan horse to bring the egg into the brood cell. The latter seems to be the much more frequent mechanism. The mobile larva of $H$. rutilans climbs onto the beewolf larva, kills it, and feeds on the host larva and the bees. Thus, infestation by H. rutilans inevitably leads to a fitness reduction of the host. $H$. rutilans is considered to be the most important brood parasite of $P$. triangulum. The rate of parasitism varies between $3 \%$ and more than $30 \%$ ([4,24-26], E. Strohm, unpubl. data). $H$. rutilans might even drive local aggregations of $P$. triangulum to extinction [25].

In both oviposition strategies, detection of the cuckoo wasp female by the beewolf female might decrease the cuckoo wasp's success. First, when encountered in the nest, cuckoo wasps might be carried to the nest entrance by beewolf females and thrown out [27]. Mostly, cuckoo wasps are not severely harmed due to the solidity and strong sculpturing of their cuticle and their ability to adopt a rolled-up defensive posture that protects the most vulnerable parts of the body (legs, mouthparts, antennae $[22,28])$. Nevertheless, the wings are rather unprotected and might be injured by a beewolf female. Second, if beewolves females detect signs of the presence of cuckoo wasps they might remove bees from the nest that have possibly been parasitized [25]. Thus, a cuckoo wasp should avoid detection to minimize wastage of time and investment. This means that cuckoo wasp females should avoid detection when they are encountered by a host female in the nest. However, it would probably be even more important for the cuckoo wasps not to leave any detectable traces of their presence when they had entered the nest and oviposited on a paralyzed honeybee.

In order to assess whether beewolf females respond to the presence of $H$. rutilans females at all we observed the behavioral interactions outside of the nest. To test whether $H$. rutilans females employ chemical camouflage inside the nest we conducted to sets of behavioral experiments. First, in observation cages we recorded the interaction of the cuckoo wasps with beewolf females inside the nest burrow. Second, we conducted a recognition bioassay by assessing the response of beewolf females towards filter discs treated with different extracts: solvent only, cuticular extracts of another chrysidid, Chrysis virid- ula, and cuticular extracts of $H$. rutilans. We predicted that beewolf females should ignore the discs treated with solvent only (negative control), they should respond to the discs treated with C. viridula extract (positive control) and they should not (or only weakly) respond to H. rutilans extracts.

There are two evolutionary options for $H$. rutilans femalesto avoid olfactory detection by beewolves. First, cuckoo wasps could mimic the odor of the honeybees that are temporarily couched in the main burrow. Second, $H$. rutilans females might mimic their beewolf host. We consider the imitation of the cuticular compounds of the beewolf host the better alternative, since the host's hydrocarbon profile can be found all over the nest walls due to the digging activity (Kroiss and Strohm unpubl. data) and also on the honeybees. This is because in order to prevent the paralyzed bees from molding they are treated by the beewolf females with a secretion from the postpharyngeal gland that is identical to the beewolves' cuticular hydrocarbons [29-31].

To assess both alternatives, we analyzed the composition of cuticular compounds of beewolf females, cuckoo wasps, and honeybees. Furthermore, we included beewolf males as the a priori most similar group to beewolf females and, thus, a crucial comparison for assessment of this hypothesis. To control for the possibility that chrysidids and crabronids have similar patterns of cuticular hydrocarbons by chance we also analyzed closely related species: the chrysidid wasp Hedychrum nobile and its crabronid host Cerceris arenaria (subfamily Philanthinae, a weevil hunting wasp). A reasonable null hypothesis for the resemblance among the species under study might be based on their phylogenetic relationship. Crabronids and apids are closely related and constitute the superfamily Apoidea, whereas chrysidids branch off very early $[32,33]$. Thus, the null hypothesis would predict that the cuticular profiles of beewolf females should be most similar to conspecifics males and Cerceris females, fairly similar to honeybees, and least similar to cuckoo wasps. Accordingly from a phylogenetic point of view, the chemical profiles of the two congeneric chrysidid species should be most similar to each other.

\section{Results \\ Are cuckoo wasps detected by beewolf females outside the nest?}

Cuckoo wasps flew over the beewolf nesting site and selectively landed on the mounds of beewolf nests. During the 54 hours of observation we recorded 1024 landings of $H$. rutilans on beewolf nest mounds. In 259 cases (25.3\%), cuckoo wasps flew off after $\leq 4$ seconds. In 765 cases $(74.7 \%)$ they remained on or in the vicinity of the nest mound for $\geq 4$ seconds, the duration of these stays was 74 
$\pm 250 \mathrm{~s}$ (median $=11 \mathrm{~s}$ ). During these stays the cuckoo wasps moved on the nest mound, vigorously antennating the surface. During prolonged stays at the nest, cuckoo wasps often moved to shaded areas and sometimes even placed themselves under some nearby structures like leaves. In 37 of the 765 cases the entrance was open and cuckoo wasps entered the nest for 13 - 270 s (mean: 118 \pm 133 s, median: $60 \mathrm{~s}$ ). In the remaining 728 cases the entrance was closed. Nevertheless, in 41 of these cases cuckoo wasps tried to dig through the closure; in 29 cases they abandoned digging after some time. In the 12 remaining cases they dug through the nest closure and stayed in the nest for 14 to $1263 \mathrm{~s}$ (mean: $384 \pm 421 \mathrm{~s}$, median $213 \mathrm{~s}$ ). During the observation time we observed 89 beewolf females returning with a paralyzed honeybee and entering their nests. In four of these cases we observed attempts of cuckoo wasp females to attach to a honeybee that was carried by a beewolf female while entering the nest with its prey. In all four cases, the female detected the parasitoid and drove it away. In another 11 cases (of the 89) cuckoo wasps were driven away by homing beewolf females although they did not approach the prey laden female to oviposit. In one of these cases the beewolf female grasped the cuckoo wasp with her mandibles. Sometimes (46 cases of 765 cases), cuckoo wasps were driven away from a nest mound by the approach of another cuckoo wasps. Although in one of the 89 cases the cuckoo wasp was in the nest when the beewolf female returned with a bee, it was not thrown out of the nest.

\section{Are cuckoo wasps detected inside nests?}

\section{a) Experiment I}

In observation cages in the laboratory, $H$. rutilans females $(\mathrm{N}=7)$ were observed to enter beewolf nests $(\mathrm{N}=6$ beewolf nests) and oviposit on the couched bees $(\mathrm{N}=4)$. Although in five cases the beewolf female entered the nest while a cuckoo wasp was present and came close to (less than $2 \mathrm{~cm}, \mathrm{~N}=5)$ or even passed $(\mathrm{N}=3)$ the cuckoo wasp in the burrow, the host female did not show any signs of detection of the brood parasitoid or disturbance. Notably, the cuckoo wasp either ran to a distant part of the nest when a beewolf female approached or it remained motionless at the periphery of the nest burrow until the female had passed.

\section{b) Experiment II}

In the recognition bioassay (Figure 1), beewolf females always responded to the positive control (C. viridula extract), they never responded to the negative control (solvent only), and they only rarely responded to the test discs (H. rutilans extract). The difference in response frequency between $H$. rutilans and $C$. viridula extracts was significant (Fisher's exact test: $\mathrm{P}=0.0101$, Figure 1) whereas there was no statistical difference between $H$. rutilans extracts and the negative control (Fisher's exact test: $P=1$, Figure

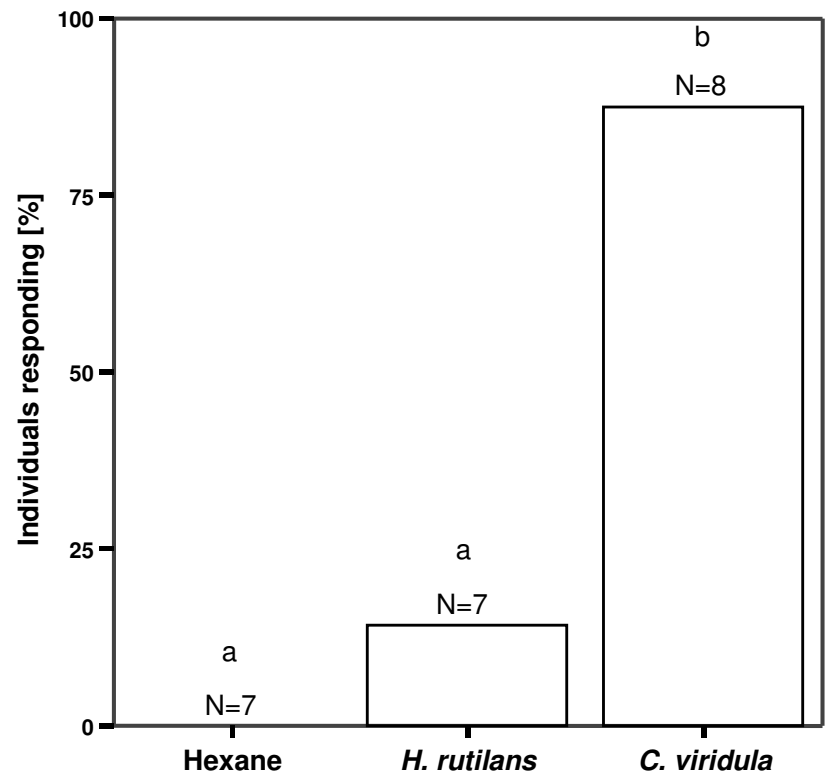

Figure I

Recognition bioassay. Percentage of beewolf females showing a response towards filter paper discs treated with hexane (negative control, left), cuticular extract of $H$. rutilans females (middle), and cuticular extract of $C$. viridula females (right). Different letters above the bars indicate significant differences between groups (Fisher's exact test: $P<0.05$ ).

1). This result shows that the chemical signal consisting of cuticular extracts of $H$. rutilans elicits much weaker behavioral responses in beewolf females than extracts of a closely related chrysidid species. Thus, we hypothesized that $H$. rutilans females are chemically camouflaged.

\section{Are cuckoo wasps chemically cloaked?}

The GC-MS analyses revealed alkanes, alkenes, and mono- and dimethylalkanes as the predominant hydrocarbons in all species. We found between 12 and 34 substances on the cuticles of the five species (Table 1). $H$. rutilans females shared 10 compounds with beewolf females, 9 with beewolf males, 13 with $H$. nobile, 11 with honeybees, and 14 with C. arenaria females.

The cuticles of honeybees contained a varying proportion of saturated and unsaturated hydrocarbons with a chain lengths ranging from $\mathrm{C} 25$ to $\mathrm{C} 33$. The profile of beewolf females is characterized by a very high proportion of unsaturated hydrocarbons with individuals showing either (Z)-9-C25:1 or (Z)-9-C27:1 as the main peak (for the source and possible function of this chemical dimorphism see [29-31,34-36]). Cuckoo wasps also show relatively large amounts of the unsaturated C25:1 and C27:1. In contrast to beewolves where individuals had only large proportions of one of these unsaturated compounds, $H$. 
Table I: Relative peak area of cuticular compounds.

\begin{tabular}{|c|c|c|c|c|c|c|}
\hline & $\begin{array}{l}\text { A. mellifera } \\
\text { workers }\end{array}$ & $\begin{array}{l}\text { P. triangulum } \\
\text { males }\end{array}$ & $\begin{array}{l}\text { P. triangulum } \\
\text { females }\end{array}$ & $\begin{array}{l}\text { H. rutilans } \\
\text { females }\end{array}$ & $\begin{array}{l}\text { H. nobile } \\
\text { females }\end{array}$ & $\begin{array}{l}\text { C. arenaria } \\
\text { females }\end{array}$ \\
\hline $\mathrm{C} 21$ & 0.399 & - & - & - & 0.194 & - \\
\hline $\mathrm{C} 22$ & 0.128 & - & - & - & - & - \\
\hline (Z)-I I-Eicosen-I-ol & $0.47 I$ & - & - & - & - & - \\
\hline (Z)-9-C23:I & 2.81 & 0.261 & - & - & 0.884 & - \\
\hline (Z)-7-C23:I & 0.301 & - & - & - & 0.210 & - \\
\hline $\mathrm{C} 23$ & 22.4 & 16.5 & 10.2 & 10.1 & 3.56 & 0.138 \\
\hline II-,9-MeC23 & - & - & - & - & 2.70 & - \\
\hline $7-\mathrm{MeC} 23$ & - & - & - & - & 2.69 & - \\
\hline $5-\mathrm{MeC} 23$ & - & - & - & - & 0.289 & - \\
\hline 3-MeC23 & - & - & 0.387 & 1.10 & 1.01 & - \\
\hline C24:I & 1.15 & 0.261 & - & - & - & - \\
\hline C24 & 0.508 & 0.756 & - & - & 0.213 & 0.188 \\
\hline (Z)-9-C25:I & 5.31 & 34.5 & 40.8 & 11.0 & 9.55 & 0.038 \\
\hline (Z)-7-C25:I & 0.233 & - & - & 10.6 & 3.10 & 0.087 \\
\hline $\mathrm{C} 25$ & 24.8 & 9.49 & 5.80 & 20.3 & 21.0 & 32.7 \\
\hline |3-, | |-,9-MeC25 & 0.043 & - & - & 1.95 & 9.41 & 1.22 \\
\hline 7-MeC25 & 0.010 & - & - & 0.975 & 8.33 & 0.188 \\
\hline $5-\mathrm{MeC} 25$ & - & - & - & 0.489 & 1.40 & 0.576 \\
\hline 7,II-diMeC25, 3-MeC25 & - & - & - & - & 0.710 & 0.254 \\
\hline C26:I & - & 0.281 & 0.443 & 0.211 & - & - \\
\hline $\mathrm{C} 26$ & 0.384 & - & - & - & 0.764 & 0.531 \\
\hline |3-,|12-, ||-, |0-,9-,8-,7-MeC26 & - & - & - & - & 0.639 & 0.370 \\
\hline 16-Pentacosen-8-one & - & - & 0.307 & - & - & - \\
\hline (Z)-9-C27:I & 1.93 & 2.16 & 31.2 & 13.9 & 0.683 & 0.434 \\
\hline (Z)-7-C27:I & - & - & - & 6.32 & 0.588 & 5.42 \\
\hline $\mathrm{C} 27$ & 12.9 & 5.15 & 2.51 & 10.6 & 10.9 & 7.12 \\
\hline |3-,|।-,9-,7-MeC27 & 0.368 & - & - & 1.58 & 15.0 & 25.7 \\
\hline $5-\mathrm{MeC} 27$ & - & - & - & - & 0.311 & 0.073 \\
\hline 9,I3-diMeC27 & - & - & - & - & 0.412 & 0.320 \\
\hline 7,II-diMeC27, 3-MeC27 & - & - & - & - & - & 0.223 \\
\hline 5,9-,5, II-diMeC27 & - & - & - & - & - & 0.643 \\
\hline $\mathrm{C} 28$ & 0.154 & - & - & - & 0.249 & 0.197 \\
\hline |4-,| |3-,|12-,| | -, | 0-,9-,8-,7-MeC28 & - & - & - & - & 0.286 & 0.546 \\
\hline 18-Heptacosen-10-one & - & - & 0.527 & - & - & - \\
\hline (Z)-9-C29:। & 0.341 & 0.047 & 1.38 & 0.571 & - & 0.771 \\
\hline 7-C29:1 & 0.653 & - & - & - & - & 5.00 \\
\hline $\mathrm{C} 29$ & 4.53 & 3.49 & 4.01 & 8.36 & 1.79 & 4.00 \\
\hline |3-, | |-,9-,7-MeC29 & 0.250 & - & - & - & 2.42 & 11.9 \\
\hline $5-\mathrm{MeC} 29$ & - & - & - & - & - & 0.247 \\
\hline 7,II-diMeC29+3-MeC29 & - & - & - & - & - & 0.031 \\
\hline 5,I3-,5, II-,5,9-diMeC29 & - & - & - & - & - & 0.083 \\
\hline $\mathrm{C} 30$ & - & - & - & - & - & 0.055 \\
\hline |4-,| 3-, |2-, |I-, |0-,9-,8-МeC30 & - & - & - & - & - & 0.080 \\
\hline C3I:I & 4.78 & 0.553 & - & - & - & 0.046 \\
\hline C3I:I & 0.635 & 0.491 & - & - & - & 0.098 \\
\hline $\mathrm{C} 31$ & 5.41 & 1.85 & 2.47 & 1.98 & -- & 0.246 \\
\hline |5-,|3-,|| -,9-,7-МeС3। & - & - & - & - & 0.635 & 0.490 \\
\hline C33:I & 0.762 & - & - & - & - & - \\
\hline C33:I & 7.87 & 11.7 & - & - & - & - \\
\hline C33 & 0.377 & 12.6 & - & - & - & - \\
\hline
\end{tabular}

Relative peak area (in percent, not transformed) of compounds on the cuticle of $A$. mellifera workers $(\mathrm{N}=8), P$. triangulum males $(\mathrm{N}=8), P$. triangulum females $(N=7), H$. rutilans females $N=13), H$. nobile females $(N=4)$, and $C$. arenaria females $(N=4)$.

rutilans females showed fairly large proportions of both. Furthermore, cuckoo wasps had similar proportions of the (Z)-7- and the (Z)-9-isomers of both substances (Table 1).
A cluster analysis based on the proportions of cuticular hydrocarbons as revealed by GC-MS (Figure 2) clearly separated $C$. arenaria females from all other species in the first bifurcation. The second bifurcation separated $H$. nobile 
from the honeybee workers, the beewolves, and H. rutilans. The remaining individuals were subdivided by bifurcation three into the honeybees on the one side and the beewolves and $H$. rutilans on the other side. Among beewolves and $H$. rutilans, however, the distinction was less clear-cut. The fourth bifurcation separated a group consisting of all male beewolves and four beewolf females (that shared (Z)-9-C25:1 as the major component) from a group consisting of the other three beewolf females (that shared (Z)-9-C27:1 as the major component) and H. rutilans females. Thus, the cuckoo wasps most closely resemble beewolf females exhibiting (Z)-9-C27:1 as their major cuticular compound. Only bifurcation five separated the $H$. rutilans females from the three beewolf females of that cluster. According to this analysis, $H$. rutilans females are

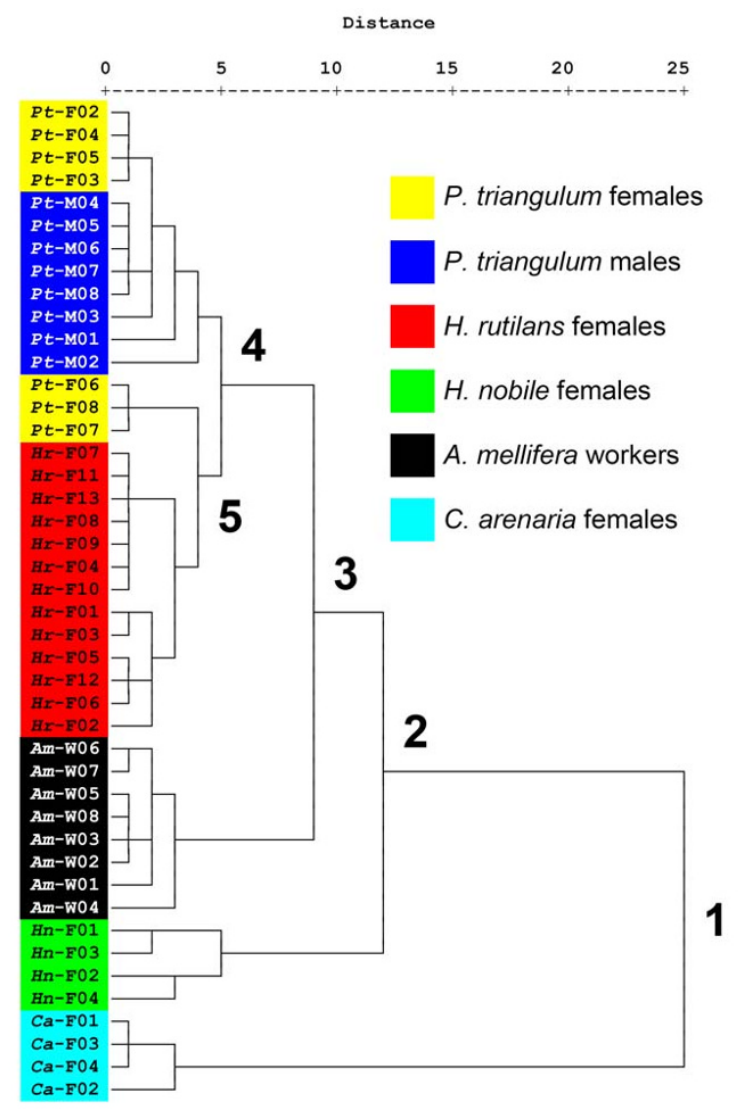

\section{Figure 2}

Dendrogram based on the cluster analysis of the cuticular compounds. Included are individual $P$. triangulum females $(=P t-F), P$. triangulum males (= Pt-M), $H$. rutilans females $(=H r-F), A$. mellifera workers $(=A m-W), C$. arenaria females $(=\mathrm{Ca}-\mathrm{F})$, and $\mathrm{H}$. nobile females $(=\mathrm{Hn}-\mathrm{F})$. Numbers after the species label indicate the different individuals. Numbers in the dendrogram indicate the first 5 bifurcations (see text). considerably more similar to beewolf females than to females of the closely related $H$. nobile, and are about as similar to beewolf females as beewolf males.

The discriminant analysis, that followed the principal component analysis, calculated five discriminant functions that resulted in a complete separation of the six groups (Wilk's $\Lambda<0.001$, d.f. $=40, \mathrm{P}<0.001$; Figure 3, Table 2). Discriminant function 1 represented $75.8 \%$ of the variance and clearly separated females of both C. arenaria and $H$. nobile from the other groups. Discriminant function 2 represented $10.8 \%$ of the variance and separated honeybees from a group consisting of male and female beewolves and $H$. rutilans females. Discriminant functions $3(10.1 \%$ of the variance) and $4(2.2 \%$ of the variance) separated beewolf males from beewolf females. Only discriminant function 4 and discriminant function 5 (1.1\% of the variance) separated beewolf females from $H$. rutilans females. Thus, although $H$. rutilans females can be separated from beewolf females using GC-MS and discriminant analysis, the amount of variance that allows this separation is very small.

\section{Discussion}

Beewolf females often attacked and evicted $H$. rutilans when they encountered them in front of their nest. This seems to be the rule for interactions between hosts and chrysidids although Linsenmaier [37] reported that there are also cases where chrysidids do not elicit antagonistic behavior by their hosts. Prolonged stays at hosts' nests as observed in $H$. rutilans, have also been reported for other chrysidids $[22,37,38]$. Staying in vicinity of the host nest might allow the chrysidids to adjust the timing of oviposition to the most suitable stage of the provisioning cycle or to enter the nest in the absence of the host female. That $H$. rutilans females placed themselves under some cover (e. g. leaves) during prolonged stays might, besides the reduction of water loss, represent an attempt to hide themselves from the host females. Other chrysidid species also seem to hide near the entrance of a host nest and inspect the nest or brood cell after the host female has deposited provisions and departed for a new foraging flight [37]. This suggests that, similar to beewolves, most host species might recognize cuckoo wasps visually outside the nest. Since most chrysidids are brightly colored (see e.g. drawings in [37]) this is not surprising.

However, there was no evidence that $H$. rutilans females were recognized by beewolf females in their nests although the nest owners approached the chrysidids several times. In contrast to Olberg's few reported cases [27], we could never observe that chrysidids were thrown out of the nest by beewolf females neither in the study population in the field, nor in observation cages in the laboratory, nor during prolonged observations of beewolf nest 

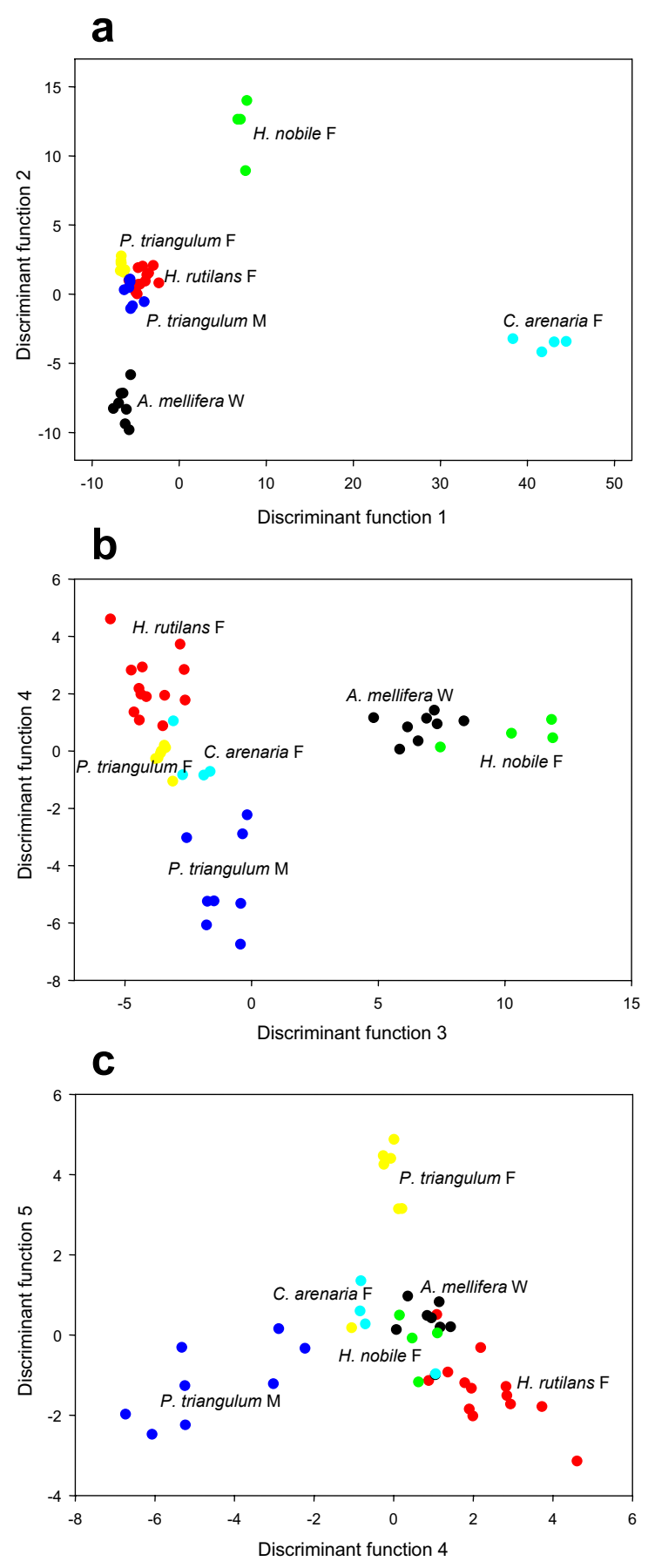

Figure 3

Discriminant analysis of the cuticular compounds. Included are individual $P$. triangulum females (yellow), P. triangulum males (blue), $H$. rutilans females (red), $A$. mellifera workers (black), C. arenaria females (turquoise), and $H$. nobile females (green): Representation of the six groups for five discriminant functions a: Discriminant functions (DF) I and 2; b: DF 3 and 4; c: DF 4 and 5. The analysis is based on 8 factors revealed by the principal component analysis. aggregations as part of another study [4]. Possibly, different populations show varying local adaptations in the defense of the parasitoid or this behavior is extremely rare. However, we can not exclude that the chrysidids that Olberg [27] saw were not $H$. rutilans. Anyhow, our observations suggest that the $H$. rutilans females are often not detected in the nests. This finding is supported by the recognition bioassay. Filter paper discs treated with an extract of $H$. rutilans were recognized significantly less frequently than paper discs treated with an extract of the "alien" cuckoo wasp C. viridula. This suggests that the properties of the cuticular hydrocarbons of $H$. rutilans allow the cuckoo wasp to avoid recognition either when encountered inside the nest or after visiting the nest for inspection or oviposition. Our observations furthermore suggest that in the vast majority of cases $H$. rutilans females enter the nest when the female is out foraging and that they are only rarely directly encountered by the nest owner. Thus, it seems most important not to leave traces in the burrow during inspection of the nest or oviposition.

There are numerous reports of parasites of social species that gain access to their hosts' nests and protection from attacks mainly by chemical camouflage and more rarely chemical mimicry $[19,39-45]$ see also $[46,47]$ for examples of chemical mimicry of sex pheromones in sexually deceptive orchids). Hydrocarbons are considered to represent the principal cues for nestmate recognition in social bees and wasps [41] and are most probably also involved in nest identification and species recognition in solitary species [48]. In our analysis, the GC-MS profiles of the cuticular hydrocarbons of $H$. rutilans and beewolf females show considerable similarity. At least, the null hypothesis based on the phylogenetic relationship of a closer resemblance between the two Hedychrum species as well as the two philanthine species was clearly contradicted. Our preliminary analysis of other species of chrysidids apart from $H$. nobile showed also distinct differences to the profile of H. rutilans (J. Kroiss, T. Schmitt, P. Schreier, E. Strohm, unpubl. data). Furthermore, other aculeate Hymenoptera show considerably different compositions of cuticular compounds [49-52]. This clearly contradicts a general similarity among all Hymenoptera or all aculeates or between chrysidids and crabronids. The profiles of the $H$. rutilans females were as close as or even closer to beewolf females than the profiles of beewolf males. Together with the behavioral tests, this provides strong evidence that $H$. rutilans females are chemically cloaked. This will help to reduce the probability of detection during or -more importantly-after their presence in the nest.

A priori, chemical camouflage and mimicry seem unlikely to evolve in a chrysidid wasp that attacks a solitary host. Chemical camouflage, i.e. the acquisition of mimetic compounds from a solitary host by a parasitic species, 
might be problematic since, in contrast to parasites of social hosts, there is little opportunity to sequester cloaking chemicals. Social host species possess large nests and a large number of colony members that might serve as sources for the relevant compounds. Brood parasites of solitary brood caring Hymenoptera have rarely been studied in detail [53]. The only example of chemical camouflage in a brood parasite of a solitary species comes from Nomada bees. In some species of this genus, females have been reported to acquire mimetic odors by being perfumed by males during mating. Females of these species seemed not to elicit aggressive responses when encountered by host females of the genus Andrena [2]. Chemical cloaking in chrysidid wasps has not yet been reported.

With chemical camouflage being an unlikely option for a brood parasite of solitary species, chemical cloaking might evolve by synthesis of the compounds, i.e., chemical mimicry. For most chrysidids this is also unlikely since they attack a large number of different host species [22] with a varying composition of cuticular chemicals that is not compatible with an efficient chemical cloaking. However, $H$. rutilans is de facto monospecific in the study area and is, thus, predestined to evolve chemical mimicry. The behavioral observations show that cuckoo wasps do not regularly stay in nests for long periods. This makes a sequestration of host chemicals that are only available in relatively small amounts at the walls of the burrow rather unlikely. The assumption that the cloaking compounds are synthesized by $H$. rutilans females themselves is supported by details of the composition of chemicals on their cuticle. The occurrence of considerably proportion of the $(Z)-7$ isomers of the respective major components of the beewolf cuticle ((Z)-9-C25:1 or (Z)-9-C27:1) in the brood parasitoid but the lack thereof (at least in comparable proportions) in beewolf females contradicts an acquisition of the chemicals from their host. Thus, most probably cuckoo wasps produce at least some of the compounds on their cuticle by themselves.

In addition to the qualitative imitation of the hydrocarbons of its host, the cuckoo wasps might also employ a quantitative strategy to evade detection by beewolf females. Preliminary data suggest that $H$. rutilans (as well as several other chrysidids studied by us) have an overall low level of cuticular substances (Kroiss, Schmitt, Strohm, unpubl. data). Such a reduction in the amount of cuticular hydrocarbons as a means to avoid detection by the host has been suggested by Jeral et al. [54] in thievery ants (see also [41]). In fact, the background against which the cuckoo wasp is perceived (or rather not perceived) by the beewolf female is the wall of the nest burrow. This is contaminated with compounds from the cuticle of the nest owner due to the contact with its mandibles during excavation and with the tarsi and abdomen during processing of the excavated sand and movement inside the nest. Preliminary analyses suggest that the typical beewolf cuticular hydrocarbons can be sampled from the nest walls (Kroiss and Strohm, unpubl. data). Thus, the chemical traces or the presence of a cuckoo wasp whose hydrocarbon profile is sufficiently similar to the background might not be recognized by a beewolf female.

\section{Conclusion}

H. rutilans might employ a combination of strategies to evade detection. If encountered in the nest, they run away or remain motionless. They possibly leave only very small amounts of decisive and traitorous substances in the nest. Most notably, the composition of their cuticular hydrocarbons is very similar to that of their host. Thus, $H$. rutilans females seem to be able to avoid detection when directly encountered by a beewolf female in the nest. Much more important, however, is the reduction of the conspicuousness of scent marks left in the nest burrow or on the bee during oviposition. This is to our knowledge the first reported evidence for chemical mimicry (sensu [19]) in a parasitoid of a solitary wasp.

\section{Methods \\ Behavioral observations \\ Behavior outside the nest}

We observed interactions between cuckoo wasps (H. rutilans)and beewolf females in the field in a beewolf nest aggregation on the Campus of the University of Würzburg. Over several years there were about 100 - 500 beewolf nests (easily detectable due to the characteristic nest mounds) and $50-500 \mathrm{H}$. rutilans females (determined by capture-mark-recapture methods [55], E. Strohm, unpubl. data). Behavioral interactions between beewolf females and cuckoo wasps at 24 focal nests (located on an area of about $10 \times 5 \mathrm{~m}$ ) were recorded for a total of 54 hours. We observed whether beewolf females showed any signs of disturbance or agonistic behavior when a cuckoo wasp was present in the vicinity of their nests. We recorded the following behaviors of cuckoo wasps and beewolf females: 1 . Landing of $H$. rutilans on nest mound. 2 . Time it stayed on nest mound (for stays $>4 \mathrm{sec}$.). 3 . Whether the nest was open or closed. 4. Whether the cuckoo wasp entered the nest. 5. The time the cuckoo wasp stayed in the nest and whether the nest owner was at home or not. 6 . Behavior of the cuckoo wasp during its stay outside the nest (running, sitting hiding, no exact durations were recorded). 7 . Whether the cuckoo wasp tried to oviposit on a bee when a female returned with prey. 8 . Whether and how a female responded to the presence of a cuckoo wasp when returning with prey. 
Table 2: Group centroids for the discriminant analysis.

\begin{tabular}{|c|c|c|c|c|c|}
\hline \multirow[b]{2}{*}{ species } & \multicolumn{5}{|c|}{ discriminant function } \\
\hline & I (75.8\%) & $2(10.8 \%)$ & $3(10.1 \%)$ & $4(2.2 \%)$ & $5(1.1 \%)$ \\
\hline H. rutilans females & -4.239 & 1.064 & -3.980 & 2.312 & -1.359 \\
\hline P. triangulum females & -6.591 & 2.100 & -3.512 & -0.187 & 3.498 \\
\hline P. triangulum males & -5.507 & 0.170 & -1.122 & -4.593 & -1.205 \\
\hline A. mellifera workers & -6.414 & -7.978 & 6.651 & 0.874 & 0.283 \\
\hline C. arenaria females & 41.874 & -3.566 & -2.335 & -0.332 & 0.316 \\
\hline H. nobile females & 7.279 & 12.050 & 10.360 & 0.583 & -0.175 \\
\hline
\end{tabular}

Given are the respective group means of the five discriminant functions (percent explained variance).

Behavior inside the nest

a) Experiment 1

The interaction between host and parasite inside the nest was investigated using observation cages in the laboratory (for details see [20]). These cages allow observation of the behavior of host and parasite in the main burrow. Beewolf females $(N=6)$, either from the laboratory population or from the field were kept individually in such cages and one cuckoo wasp that was caught in the field was introduced per cage (overall $7 \mathrm{H}$. rutilans females were used). Honey was provided ad libitum for both species. Honeybees were also provided ad libitum as prey for the beewolves. Since a pilot study revealed that the cuckoo wasps need a humid retreat, petri-dishes with a layer of moist sand and gravel were placed into the flight compartment of each cage and moistened daily. Observations of interactions in the nest burrow were carried out under dimmed red light that did not elicit any disturbance in either species. If a cuckoo wasp and a female were in a nest at the same time, we recorded the behavior of both.

\section{b) Experiment II}

To assess the significance of the cuticular hydrocarbons for the detection of $H$. rutilans beewolf female inside the nest, we established a recognition bioassay. We recorded the females' response towards paper discs treated with extracts. To make sure that beewolf females responded to the paper discs at all, we needed a positive control, i.e., extracts from a species that was recognized as an intruder and elicited strong responses by beewolf females. We used extracts of another chrysidid, Chrysis viridula (although it might have been preferable to use extracts of $H$. nobile, fresh specimens of this species were not available due to their rarity). C. viridula is a parasitoid of eumenid wasps and it may occur in the same habitat as $H$. rutilans. Its cuticular hydrocarbons differ considerably from the composition of the cuticular hydrocarbons of $H$. rutilans (Kroiss and Strohm, unpubl. data). Both cuckoo wasp species are very similar in size and the total amount of their cuticular hydrocarbons is alike (J Kroiss, E. Strohm, unpublished data). Cuticular hydrocarbons of females of H. rutilans and Chrysis viridula were extracted for $10 \mathrm{~min}$ in
$0.5 \mathrm{ml}$ distilled $\mathrm{n}$-hexane (Fluka). The hexane of the cuticular extracts was evaporated under a stream of nitrogen at ambient temperature and the extract was redissolved in $100 \mu \mathrm{l}$ hexane. An aliquot of $10 \mu \mathrm{l}$ of an extract was applied onto a circular filter paper disc (diameter $6 \mathrm{~mm}$. H. rutilans: $\mathrm{N}=7$, C. viridula: $\mathrm{N}=8$ ) and the solvent was allowed to evaporate for $5 \mathrm{~min}$. As a negative control 10 $\mu \mathrm{l}$ of pure hexane were applied onto a filter paper disc and evaporated $(\mathrm{N}=7)$. The filter paper discs were inserted into the main burrow of individual beewolf nests $(\mathrm{N}=9)$ in observation cages (see above) one after the other in a randomized sequence. After introduction of the filter disc we continuously recorded the behavior of individual beewolf females using a voice recorder until the paper disc was evicted from the nest or until it was incorporated into excavated material in the nest. Beewolf females biting a paper disc or alert freezing directly at the paper disc when approaching it at any time during a trial were considered as evidence that a female has recognized the paper disc as something that differed from the background odor. The freezing behavior was distinctive and could not be observed as a spontaneous behavior. If one or several of these behaviors occurred the respective trials was considered as showing a response by the beewolf female. In contrast, trials during which females were walking over the paper disc without any response were classified as "no recognition". The prediction that extracts of $H$. rutilans elicited weaker responses than the positive control and similar responses as the negative control was tested by comparing the number of trials with and without recognition. The small sample size necessitated using Fisher's exact tests.

\section{Chemical analyses}

We caught females of $H$. rutilans $(\mathrm{N}=13)$ in the vicinity of beewolf nests on the campus of the University of Würzburg. Beewolf females $(\mathrm{N}=7)$ and males $(\mathrm{N}=8)$ were taken from the same field site in Würzburg or from a laboratory population that was bred from the same population. Honeybee foragers (Apis mellifera carnica) $(\mathrm{N}=8)$ were caught from hives in the vicinity of the field site when leaving the nest. Females of Hedychrum nobile 
(Hymenoptera, Chrysididae) $(\mathrm{N}=4)$ and its host, Cerceris arenaria (Hymenoptera, Crabronidae, subfamily Philantinae) $(\mathrm{N}=4)$ were caught at a nesting aggregation near Vizzola Ticino, Italy. These two species are another hostparasitoid pair and served as an outgroup for $H$. rutilans and $P$. triangulum to control for phylogenetic relationships. All individuals were killed by freezing $\left(1 \mathrm{~h},-20^{\circ} \mathrm{C}\right)$. Chemicals on their cuticles were extracted for $10 \mathrm{~min}$ in $0.5 \mathrm{ml}$ distilled n-Hexane (Fluka).

Capillary gas chromatography-mass spectrometry (GCMS)-analysis was performed with a Fisons Instruments (Fisons, Engelsbach, Germany) GC 8000 Series coupled to a Fisons Instruments MD800 quadrupol mass detector. We used a DB-5MS fused silica capillary column (30 $\mathrm{m} \times$ $0.25 \mathrm{~mm}$ i.d.; $\mathrm{df}=0.25 \mu \mathrm{m})(\mathrm{J} \& \mathrm{~W}$, Folsom, CA, USA). The GC was programmed from $60^{\circ} \mathrm{C}$ for 1 min then to $310^{\circ} \mathrm{C}$ for $10 \mathrm{~min}$ with a temperature increase of $5 \% \mathrm{~min}$, with $2 \mathrm{ml} / \mathrm{min}$ flow rate of helium gas. We chose a splitless injection mode $(1 \mu \mathrm{l})$ at an injector temperature of $250^{\circ} \mathrm{C}$ and a splitless period of $60 \mathrm{sec}$. The mass spectrometer was operated in EI mode at $70 \mathrm{eV}$. The software Xcalibur for Windows was used for data acquisition.

Capillary Gas Chromatography - Fourier Transform Infrared Analysis (HRGC-FTIR). HRGC-FTIR spectra were obtained using an HP 5890 GC (Agilent Technologies, Böblingen, Germany) coupled to an FTS 575C Tracersystem (BioRad, Hercules, CA, USA). GC separation was performed using a DB-1 capillary column $(30 \mathrm{~m} \times 0.25 \mathrm{~mm}$ $\mathrm{ID} ; \mathrm{df}=0.25 \mu \mathrm{m}$; J \& W Scientific, Folsom, CA, USA). Temperature was programmed from 80 to $270^{\circ} \mathrm{C}$ with $4{ }^{\circ} \mathrm{C} /$ min heating rate. Helium was used as carrier gas with a constant flow of 1-2 $\mathrm{ml} / \mathrm{min}$. Injection was carried out using a split/splitless injector at $250^{\circ} \mathrm{C}$ in the splitless mode for $60 \mathrm{sec}$. Injection volume was $0.1 \mu \mathrm{l}$. IR spectra were recorded by scanning 256 times in a frequency range from 4000 to $700 \mathrm{~cm}^{-1}$ with a resolution of $1 \mathrm{~cm}^{-1}$. Data system was a Dell Optiplex GX110-PC with BioRad WinIR Pro (Version 2.7) Tracer Software and Sadtler IRSearchMaster.

The chemical structure of the components of the cuticular hydrocarbons was determined by comparing retention times and diagnostic ions of the mass spectra with purchased chemicals and the use of a commercial MS database (NIST 4.0). Methylalkanes were characterized using diagnostic ions and by determining Kovats indices according to the method of Carlson et al. (1998). The position of double bonds was determined by DMDS derivatisation [56]. The configuration of double bonds was revealed by HRGC-FTIR $[57,58]$. Some components could not be identified and for some alkenes the position of the double bond and its configuration could not be determined due to the small amounts on the cuticles. However, neither of the unidentified components occurs on beewolf females and cuckoo wasps. Thus, they do not confound the similarity between these two groups that are most important to our question. The alkenes listed in one line in Table 1 as the same compound for beewolves, cuckoo wasps and honeybees are most probably identical since their mass spectra and the retention times are identical. Thus, the comparison between beewolf females and cuckoo wasps is not confounded by the incompletely identified alkenes.

\section{Data analysis}

The results of the behavioral observations are given as the mean \pm SD and/or the median. For the recognition bioassay, we compared the number of individuals showing a response facing the paper disc between the treatments. Different treatments were compared using Fisher's exact test (two-tailed) using the program BIAS for Windows version 8.2 (epsilon-Verlag GbR, H. Ackermann, Frankfurt/ Main, Germany). Since some of the females died before their response to all stimuli could be tested, sample sizes differ between the three stimuli.

Patterns of chemicals on the cuticle were analyzed by multivariate methods. Since we were interested in the similarity between $H$. rutilans females beewolf females, beewolf males, honeybee workers, $H$. rutilans females, and $H$. nobile and C. arenaria females, we performed a hierarchical cluster analysis to assess the pattern of similarity without a priori grouping. Furthermore, we conducted a discriminant analysis to test whether the groups are separated by discriminant functions. Due to the large number of peaks relative to the sample size the discriminant analysis might lead to confounded results with regard to the hypothesis tested. Thus, we reduced the number of variables for the discriminant analysis using principal component analysis (varimax rotation, eigenvalues $>1 ; 8$ variables were extracted that represented $89 \%$ of the variance of the total sample).

Since relative peak areas of a sample are not statistically independent we transformed the data according to Aitchison ([59] see e.g. [60]). However, the original transformation procedure makes it necessary to exclude compounds that do not occur in all samples. Thus, peaks that are zero in some samples but are present in other samples would not have been considered. When analyzing whether groups can be separated by their profiles such a procedure is conservative. However, for the aim of this study, the exclusion of peaks that are not present in all samples would have erroneously increased the similarity between the groups and, thus, confounded the result. Therefore, we modified the transformation to avoid undefined values for peaks with an area of zero $(\log 10(($ relative peak area/geometric mean relative peak area)+1)). The resulting variables were normally distributed. We used the 
squared Euclidean distance as a measure of distance for cluster analysis and between groups average linkage as the method for combining clusters. Analyses were calculated using SPSS 13.0.1.

\section{Competing interests}

The author(s) declare that they have no competing interests.

\section{Authors' contributions}

The manuscript was written by ES and JK. ES conceived the study, collected $H$. rutilans and $P$. triangulum, designed and conducted the statistical analysis. JK collected $H$. nobile and C. arenaria, performed the recognition bioassay, participated in the statistical analysis and the identification of the cuticular hydrocarbons of $H$. nobile and $C$. arenaria. GH participated in the quantitative analysis of the cuticular hydrocarbons. CLK conducted preliminary studies on the behavioral interaction. WB participated in the identification of the cuticular hydrocarbons in this preliminary study. PS participated in the identification of the cuticular hydrocarbons. TS identified the cuticular hydrocarbons. All authors read and approved the final manuscript.

\section{Acknowledgements}

This study was supported by the Deutsche Forschungsgemeinschaft, SFB 554 , TP B3 and STR 532/I-2. Collection of specimens in Italy was made possible by a travel grant from the Arthur von Gwinner foundation to JK. Gerhard Krammer is acknowledged for his help with the HRGC-FTIR. We thank Sabrina Bauer for her help with the recognition bioassay and Martin Kaltenpoth for doing the observations in front of the nest.

\section{References}

I. Godfray HC): Parasitoids Behavioral and Evolutionary Ecology. Princeton, NJ, Princeton University Press; 1994.

2. Tengo J, Bergstrom G: Cleptoparasitism And Odor Mimetism In Bees - Do Nomada Males Imitate Odor Of Andrena Females. Science 1977, 196(4294): I I 7-III9.

3. Quicke D: Parasitic wasps. London, Chapman and Hall; 1997.

4. Strohm E, Laurien-Kehnen C, Bordon S: Escape from parasitism: Spatial and temporal strategies of a sphecid wasp against a specialised cuckoo wasp. Oecologia Berlin 200I, I 29(I):50-57.

5. Rosenheim JA: Parasite presence acts as a proximate cue in the nest-site selection process of the solitary digger wasp, Ammophila dysmica (Hymenoptera: Sphecidae). Journal of Insect Behavior 1988, 1:333-342.

6. Dawkins R, Krebs JR: Arms races between and within species. Proceedings of The Royal Society of London Series B-Biological Sciences | 979, 205(II6I):489-5 II.

7. Davies NB, Bourke AFG, Brooke MD: Cuckoos and parasitic ants - interspecific brood parasitism as an evolutionary armsrace. Trends in Ecology \& Evolution 1989, 4(9):274-278.

8. Brandt M, Heinze J, Schmitt T, Foitzik S: A chemical level in the coevolutionary arms race between an ant social parasite and its hosts. Journal Of Evolutionary Biology 2005, I 8(3):576-586.

9. Foitzik S, Fischer B, Heinze J: Arms races between social parasites and their hosts: geographic patterns of manipulation and resistance. Behavioral Ecology 2003, I4(I):80-88.

10. Lyon BE: An obligate brood parasite trapped in the intraspecific arms race of its hosts. Nature 2004, 432:390-393.

II. Spencer KC: Chemical mediation of coevolution. New York, Academic Press; 1998.

12. Sick M, Ayasse M, Tengo J, Engels W, Lubke G, Francke W: HostParasite Relationship in Six Species of Sphecodes Bees and their Halictid Hosts: Nest Intrusion, Intranidal Behavior, and Dufour's Gland Volatiles (Hymenoptera- Halictidae). Journal of Insect Behavior 1994, 7(1): 101-1 I7.

13. Jacob-Remacle A: Mortalité de quelques hyménoptéres aculéates nidifiant dans des nichoirs-pièges. Bulletins Annuels de la Societe royale belge Entomologie 1986, 122:107-II8.

14. Evans HE, O'Neill KM: The natural history of North American beewolves. Ithaca, NY, Cornell University Press; 1988.

15. Wilson EO: The Insect Societies. Belknap Press, Cambridge, London; 197I.

16. Kimsey LS, Bohart RM: The chrysidid wasps of the world. New York, Oxford University Press, 1990.

17. Jackson BD, Morgan ED: Insect chemical communication: pheromones and exocrines glands of ants. Chemoecology 1993, 4:I25-I44.

18. Herzner G, Schmitt T, Linsenmair KE, Strohm E: Prey recognition by females of the European beewolf and its potential for a sensory trap. Animal Behaviour 2005, 70:14II-14|8.

19. Dettner K, Liepert C: Chemical mimicry and camouflage. Annual Review of Entomology 1994, 39:129-154.

20. Strohm E: Allokation elterlicher Investitionen beim Europäischen Bienenwolf Philanthus triangulum Fabricius (Hymenoptera: Sphecidae). Berlin , Verlag Dr. Köster; 1995.

21. Strohm E, Linsenmair KE: Measurement of parental investment and sex allocation in the European beewolf Philanthus triangulum F. (Hymenoptera: Sphecidae). Behavioral Ecology and Sociobiology 1999, 47(1-2):76-88.

22. Kunz PX: Die Goldwespen (Chrysididae) Baden-Wurttembergs. In Beihefte zu den Veroeffentlichungen fuer Naturschutz und Landschaftspflege in Baden-Wuerttemberg Volume 77. Karlsruhe, Landesanstalt für Umweltschutz Baden - Württemberg; 1994: I 88.

23. Veenendaal RL: The hidden egg of Hedychrum rutilans (Hymenoptera: Chrysididae). Entomologische Berichten 1987, |2:169-17|.

24. Strohm E, Linsenmair KE: Allocation of parental investment among individual offspring in the European beewolf Philanthus triangulum F. (Hymenoptera: Sphecidae). Biological Journal of the Linnean Society 2000, 69(2): $173-192$.

25. Simon-Thomas RT, Simon-Thomas AMJ: Some Observations on the Behavior of Females of Philanthus-Triangulum Hymenoptera Sphecidae. Tijdschrift voor Entomologie 1972, II 5(2): 123-139.

26. Strohm E, Schmitt T, Herzner G, Schreier P: Wolves in sheep's fur? Chemical camouflage in the European beewolf and its major brood parasitoid. Zoology Jena 2002, I 05(Supplement 5):30.

27. Olberg G: Der Bienenfeind Philanthus. Leipzig, Akademische Verlagsgesellschaft Geest \& Portig; 1953.

28. Gauld I, Bolton B: The Hymenoptera. Oxford, Oxford University Press, 1996.

29. Herzner G, Schmitt T, Peschke K, Hilpert A, Strohm E: Food wrapping with the postpharyngeal gland secretion by females of the European beewolf Philanthus triangulum. Journal of Chemical Ecology 2007, 33(4):849-859.

30. Herzner G, Strohm E: Fighting fungi with physics: food wrapping by a solitary wasp prevents water condensation. Current Biology 2007, I7(2):R46-R47.

31. Herzner G, Strohm E: Food wrapping by females of the European Beewolf Philanthus triangulum retards water loss of larval provisions. Physiological Entomology 2007.

32. Brothers DJ: Phylogeny and evolution of wasps, ants and bees (Hymenoptera, Chrysidoidea, Vespoidea and Apoidea). [recognized Heterogynaidae, Ampulicidae, Sphecidae, Crabronidae, and Apidae]. Zoologica Scripta I999, 28( I-2):233-249.

33. Ronquist F: Phylogeny of the Hymenoptera (Insecta): The state of the art. Zoologica Scripta I999, 28(I-2):3-I I.

34. Strohm E, Herzner G, Kaltenpoth M, Schmitt T: The chemistry of the postpharyngeal gland of female European beewolves (Hymenoptera, Sphecidae) supports a homology with this gland in ants. 2007.

35. Strohm E, Herzner G, Boland W, Schreier P, Geiselhardt S, Peschke $\mathrm{K}$, Schmitt $\mathrm{T}$ : The chemistry of the postpharyngeal gland of female European beewolves (Hymenoptera, Crabronidae). Journal of Chemical Ecology in press. 2007

36. Strohm E, Herzner G, Goettler W: A "social" gland in a solitary wasp? The postpharyngeal gland of female European bee- 
wolves (Hymenoptera, Crabronidae). Arthropod Struct Dev 2007, 36(2): II3-122.

37. Linsenmaier W: Die Goldwespen der Schweiz. Veroeffentlichungen aus dem Natur Museum Luzern 1997, 9: I- I 40.

38. Rosenheim JA: Host location and exploitation by the cleptoparasitic wasp Argochrysis armilla: the role of learning (Hymenoptera: Chrysididae). Behav Ecol Sociobiol 1987, 21:401-406.

39. Allan RA, Capon RJ, Brown WV, Elgar MA: Mimicry of host cuticular hydrocarbons by salticid spider Cosmophasis bitaeniata that preys on larvae of tree ants Oecophylla smaragdina. Journal of Chemical Ecology 2002, 28(4):835-848.

40. Stowe MK: Chemical mimicry. In Chemical mediation of coevolution Edited by: Spencer KC. New York, Academic Press; 1998:513-580.

41. Lenoir A, D'Ettorre P, Errard C, Hefetz A: Chemical Ecology and social parasitism in ants. Annual Review of Entomology 200I, 46:573-599.

42. D'Ettorre P, Mondy N, Lenoir A, Errard C: Blending in with the crowd: social parasites integrate into their host colonies using a flexible chemical signature. Proceedings of The Royal Society of London Series B-Biological Sciences 2002, 269(1503):1911-1918.

43. Moritz RFA, Kirchner WH, Crewe RM: Chemical Camouflage of the Deaths Head Hawkmoth (Acherontia atropos L.) in Honeybee Colonies. Naturwissenschaften 199I, 78(4): 179-182.

44. Martin C, Salvy M, Provost E, Bagneres AG, Roux M, Crauser D, Clement JL, Le Conte Y: Variations in chemical mimicry by the ectoparasitic mite Varroa jacobsoni according to the developmental stage of the host honey-bee Apis mellifera. Insect Biochemistry and Molecular Biology 200I, 31:365-379.

45. Akino T, Knapp JJ, Thomas JA, Elmes GW: Chemical mimicry and host specificity in the butterfly Maculinea rebeli, a social parasite of Myrmica ant colonies. Proceedings Of The Royal Society Of London Series B-Biological Sciences 1999, 266(1 427): 1419-1426.

46. Schiestl FP, Ayasse M, Paulus HF, Löfstedt C, Hansson BS, Ibarra F, Francke W: Sex pheromone mimicry in th early spider orchid (Ophrys sphegodes): patterns of hydrocarbons as the key mechanism for pollination by sexual deception. Journal of Comparative Physiology A 2000, 186:567-574.

47. Schiestl FP, Ayasse M, Paulus HP, Löfstedt C, Hansson BS, Ibarra F, Francket W: Orchid pollination by sexual swindle. Nature 1999, 399:42I-422.

48. Singer TL: Roles of hydrocarbons in the recognition systems of insects. American Zoologist 1998, 38(2):394-405.

49. Butts DP, Camann MA, Espelie KE: Discriminant-Analysis of Cuticular Hydrocarbons Of The Baldfaced Hornet, Dolichovespula-Maculata (Hymenoptera, Vespidae). Sociobiology 1993, 2I(2): I93-20I.

50. Butts DP, Espelie KE, Hermann HR: Cuticular Hydrocarbons Of 4 Species Of Social Wasps In The Subfamily Vespinae Vespa-Crabro L, Dolichovespula-Maculata (L), VespulaSquamosa (Drury), And Vespula-Maculifrons (Buysson). Comparative Biochemistry And Physiology B-Biochemistry \& Molecular Biology $1991,99(1): 87-91$.

5I. Hadley NF: Cuticular Hydrocarbons of four species of Colorado Hymenoptera. Insect Biochemistry 198I, 255: 173-I77.

52. Howard RW, Blomquist G]: Ecological, behavioral, and biochemical aspects of insect hydrocarbons. Annu Rev Entomol 2005, 50:37I-393.

53. Hefetz A, Eickwort GC, Blum MS, Cane J, Bohart GE: A Comparative-Study Of The Exocrine Products Of Cleptoparasitic Bees (Holcopasites) And Their Hosts (Calliopsis) (Hymenoptera, Anthophoridae, Andrenidae). Journal of Chemical Ecology 1982, 8(II): 1389-1397.

54. Jeral JM, Breed MD, Hibbard BE: Thief ants have reduced quantities of cuticular compounds in a ponerine ant, Ectatomma ruidum. Physiological Entomology 1997, 22(3):207-2II.

55. Mühlenberg M: Freilandökologie. Heidelberg, UTB; 1993.

56. Dunkelblum E, TAN SH, SILK PJ: Double-bond location in monosaturated fatty acids by dimethyl sulfide derivatization and mass spectrometry: Application to analysis of fatty acids in pheromone glands of four Lepidoptera. Journal of Chemical Ecology 1985, I I:265-277.

57. Attygalle $A B$, Svatos $A$, Wilcox $C$, Voerman S: Gas-Phase InfraredSpectroscopy For Determination Of Double-Bond Configuration Of Monounsaturated Compounds. Analytical Chemistry 1994, 66(10):1696-1703.
58. Schmitt T, Strohm E, Herzner G, Bicchi C, Krammer G, Heckel F, Schreier P: (S)-2,3-dihydrofarnesoic acid, a new component in cephalic glands of male European beewolves Philanthus triangulum. J Chem Ecol 2003, 29(I I):2469-2479.

59. Aitchison J: The statistical analysis of compositional data. London, Chapman \& Hall; 1986.

60. Nielsen J, Boomsma JJ, Oldham NJ, Petersen HC, Morgan ED: Colony-level and season-specific variation in cuticular hydrocarbon profiles of individual workers in the ant Formica truncorum. Insectes Sociaux 1999, 46(I):58-65.
Publish with Bio Med Central and every scientist can read your work free of charge

"BioMed Central will be the most significant development for disseminating the results of biomedical research in our lifetime. "

Sir Paul Nurse, Cancer Research UK

Your research papers will be:

- available free of charge to the entire biomedical community

- peer reviewed and published immediately upon acceptance

- cited in PubMed and archived on PubMed Central

- yours - you keep the copyright

Submit your manuscript here:

http://www.biomedcentral.com/info/publishing_adv.asp
BioMedcentral 